\title{
Epidemiology of Trypanosomiasis in Wildlife-Implications for Humans at the Wildlife Interface in Africa
}

OPEN ACCESS

Edited by:

Elena Carreton,

University of Las Palmas de Gran Canaria, Spain

Reviewed by:

David Bruce Conn

Berry College, United States Fernando Jorge Bornay-Llinares, Miguel Hernández University of

Elche, Spain

*Correspondence:

Keneth Iceland Kasozi kicelandy@gmail.com

Susan Christina Welburn

sue.welburn@ed.ac.uk

Specialty section: This article was submitted to Parasitology,

a section of the journal

Frontiers in Veterinary Science

Received: 26 October 2020 Accepted: 05 May 2021

Published: 14 June 2021

Citation:

Kasozi KI, Zirintunda G, Ssempijja F, Buyinza B, Alzahrani KJ, Matama K,

Nakimbugwe HN, Alkazmi L,

Onanyang $D$, Bogere $P$, Ochieng $J J$, Islam S, Matovu W, Nalumenya DP, Batiha GE-S, Osuwat LO, Abdelhamid M, Shen T, Omadang $L$ and Welburn SC (2021) Epidemiology

of Trypanosomiasis in

Wildilife-Implications for Humans at

the Wildlife Interface in Africa.

Front. Vet. Sci. 8:621699

doi: 10.3389/fvets.2021.621699

\author{
Keneth Iceland Kasozi ${ }^{1,2 \star}$, Gerald Zirintunda ${ }^{3}$, Fred Ssempijja ${ }^{4}$, Bridget Buyinza ${ }^{5}$, \\ Khalid J. Alzahrani ${ }^{6}$, Kevin Matama ${ }^{7}$, Helen N. Nakimbugwe ${ }^{3,8}$, Luay Alkazmi ${ }^{9}$, \\ David Onanyang ${ }^{10}$, Paul Bogere ${ }^{11}$, Juma John Ochieng ${ }^{4}$, Saher Islam ${ }^{12}$, Wycliff Matovu ${ }^{5}$, \\ David Paul Nalumenya ${ }^{5}$, Gaber El-Saber Batiha ${ }^{13}$, Lawrence Obado Osuwat ${ }^{14}$, \\ Mahmoud Abdelhamid ${ }^{15}$, Tianren Shen ${ }^{1,16}$, Leonard Omadang ${ }^{3}$ and \\ Susan Christina Welburn ${ }^{1,16 *}$
}

\begin{abstract}
${ }^{1}$ Infection Medicine, Deanery of Biomedical Sciences, College of Medicine and Veterinary Medicine, The University of Edinburgh, Scotland, United Kingdom, ${ }^{2}$ School of Medicine, Kabale University, Kabale, Uganda, ${ }^{3}$ Department of Animal Production and Management, Faculty of Agriculture and Animal Sciences, Busitema University Arapai Campus, Soroti, Uganda, ${ }^{4}$ Faculty of Biomedical Sciences, Kampala International University Western Campus, Bushenyi, Uganda, ${ }^{5}$ College of Veterinary Medicine Animal Resources and Biosecurity, Makerere University, Kampala, Uganda, ${ }^{6}$ Department of Clinical Laboratories Sciences, College of Applied Medical Sciences, Taif University, Taif, Saudi Arabia, ${ }^{7}$ School of Pharmacy, Kampala International University Western Campus, Bushenyi, Uganda, ${ }^{8}$ Department of Agriculture, Faculty of Vocational Studies, Kyambogo University, Kampala, Uganda, ${ }^{9}$ Biology Department, Faculty of Applied Sciences, Umm Al-Qura University, Makkah, Saudi Arabia, ${ }^{10}$ Department of Biology, Faculty of Science, Gulu University, Gulu, Uganda, ${ }^{11}$ Faculty of Agriculture and Environmental Science, Muni University, Arua, Uganda, ${ }^{12}$ Department of Biotechnology, Lahore College for Women University, Lahore, Pakistan, ${ }^{13}$ Department of Pharmacology and Therapeutics, Faculty of Veterinary Medicine, Damanhour University, Damanhour, Egypt, ${ }^{14}$ School of Medicine and Health Sciences, Soroti University, Soroti, Uganda,

${ }^{15}$ Department of Parasitology, Faculty of Veterinary Medicine, Aswan University, Aswan, Egypt, ${ }^{16}$ Zhejiang University-University of Edinburgh Institute, Zhejiang University School of Medicine, Zhejiang University, Haining, China
\end{abstract}

While both human and animal trypanosomiasis continue to present as major human and animal public health constraints globally, detailed analyses of trypanosome wildlife reservoir hosts remain sparse. African animal trypanosomiasis (AAT) affects both livestock and wildlife carrying a significant risk of spillover and cross-transmission of species and strains between populations. Increased human activity together with pressure on land resources is increasing wildlife-livestock-human infections. Increasing proximity between human settlements and grazing lands to wildlife reserves and game parks only serves to exacerbate zoonotic risk. Communities living and maintaining livestock on the fringes of wildlife-rich ecosystems require to have in place methods of vector control for prevention of AAT transmission and for the treatment of their livestock. Major Trypanosoma spp. include Trypanosoma brucei rhodesiense, Trypanosoma brucei gambiense, and Trypanosoma cruzi, pathogenic for humans, and Trypanosoma vivax, Trypanosoma congolense, Trypanosoma evansi, Trypanosoma brucei brucei, Trypanosoma dionisii, Trypanosoma thomasbancrofti, Trypanosma elephantis, Trypanosoma vegrandis, Trypanosoma copemani, Trypanosoma irwini, Trypanosoma copemani, Trypanosoma gilletti, Trypanosoma theileri, Trypanosoma godfreyi, Trypansoma simiae, and Trypanosoma (Megatrypanum) pestanai. Wildlife hosts for the trypansomatidae include subfamilies of Bovinae, Suidae, Pantherinae, Equidae, Alcephinae, Cercopithecinae, Crocodilinae, Pteropodidae, Peramelidae, Sigmodontidae, 
and Meliphagidae. Wildlife species are generally considered tolerant to trypanosome infection following centuries of coexistence of vectors and wildlife hosts. Tolerance is influenced by age, sex, species, and physiological condition and parasite challenge. Cyclic transmission through Glossina species occurs for T. congolense, T. simiae, T. vivax, T. brucei, and T. b. rhodesiense, T. b. gambiense, and within Reduviid bugs for T. cruzi. T. evansi is mechanically transmitted, and T. vixax is also commonly transmitted by biting flies including tsetse. Wildlife animal species serve as long-term reservoirs of infection, but the delicate acquired balance between trypanotolerance and trypanosome challenge can be disrupted by an increase in challenge and/or the introduction of new more virulent species into the ecosystem. There is a need to protect wildlife, animal, and human populations from the infectious consequences of encroachment to preserve and protect these populations. In this review, we explore the ecology and epidemiology of Trypanosoma spp. in wildlife.

Keywords: trypanosomes in wildlife, human-wildlife interactions, wildlife-livestock interactions, human African trypanosomiasis, sleeping sickness, Trypanosoma brucei gambiense, Trypanosoma brucei rhodesiense

\section{INTRODUCTION}

The African and American trypanosomiases present significant global health challenge in human, domesticated animal, and wildlife communities. Spillover of parasites from wildlife to domestic livestock and humans and from domestic animal species to wildlife compromises health $(1,2)$. Most trypanosome infections in wildlife do not cause obvious damage to their host $(3,4)$, but some wildlife species are highly susceptible to trypanosome infections, including Rattus nativitatis and Macleay's rats (Rattus macleari) (5).

Trypanosoma are primarily transmitted by vectors (6) within which they undergo complex development cycles. Trypanosomes, which develop in the posterior section of the digestive tract in insects, are called stercorarian, for example, Trypanosoma cruzi the causal agent of Chagas disease, common in Latin America (7). Salivarian trypanosomes develop in the anterior part of the insect gut tract and include the causal agents of African animal trypanosomiasis (AAT) or nagana and for human African trypanosomiasis (HAT) caused by Trypansoma brucei rhodesiense and Trypansoma brucei gambiense that are present across Sub-Saharan Africa (8).

Animal trypanosomiasis is endemic in tropical regions of Africa, parts of Asia, and South America (9). T. brucei s.l., Trypanosoma congolense, Trypanosoma simiae, and Trypanosoma uniforme are transmitted within the tsetse belts of Africa and cannot be transmitted by mechanical vectors (9). T. vivax and Trypansoma evansi can be transmitted mechanically and occur within and outside tsetse fly-infested zones (10).

\section{EPIDEMIOLOGY OF ANIMAL TRYPANOSOMIASIS}

Trypanosomiasis is one of the most important diseases affecting livestock, equines, and dogs within the Sub-Saharan region $(11,12)$. Cross transmission of parasites between livestock and wildlife hosts has been reported, especially in areas in close proximity to game parks and wildlife reserves. Wildlife species can survive within the tsetse belts across the Sub-Saharan region, despite being reservoir hosts for multiple species of trypanosome. The high prevalence of trypanosomiasis within protected areas traditionally has rendered these areas unattractive for livestock keeping and agricultural production (13).

Phylogenetic analysis shows a remarkable complexity of trypanosome species, subspecies, and strains in tsetse flies, human, domestic, and wildlife hosts. Examining the trypanosome species circulating within an ecosystem is a key to identifying the wildlife reservoirs of infection and transmission parameters to other animal hosts, including livestock within the ecosystem (3). Understanding the various trypanosome species harbored in wildlife hosts can guide preventive and control measures of trypanosomiasis in communities living at the livestock-wildlife interface. A wide variety of trypanosome species are circulating among wildlife hosts including T. brucei s.l., T. congolense, T simiae, T. godfreyi, and T. theileri (3).

\section{Hosts and Species of Trypanosomes}

Apart from T. cruzi, present in South America, and T. theileri, present worldwide, trypanosomes infect a large number of wild and domestic ungulate species (6). Infection in the wildlife is influenced by species and habitat (12). Wildlife hosts for trypanosomiasis are numerous and include antelope species, warthogs (Paecocherus aethiopicus), elephants (Loxodanta africana), hippopotamus (Hippopotamus amphibius), lions, hyenas, jackals, caracals, and wild ruminants (14-16). Trypanosome species commonly found in wildlife species include T. vivax, T. brucei s.l., T. congolense, and T. evansi (14). T. vivax, a pathogen affecting cattle, has been identified in waterbucks and giraffes, but the strains of $T$. vivax in these two host species were unique (3). Multiple wildlife hosts carry the human-infective zoonotic trypanosome strain $T$. b. rhodesiense, including bushbucks (Tragelaphus scriptus), impala (Aepyceros melampus), lion (Panthera leo), zebra (Equus 
quagga boehma), warthog (Phacocoerus africanus), and duiker (Sylvicapra grimmia) (12). Trypanosoma conglense, Trypanosoma simiae, and Trypanosoma godfreyi were identified in Rhinocerus posttranslocation (16).

Infection with trypanosomes can predispose infected animals to other infections (17), and concurrent and opportunistic bacterial infections in wildlife can hasten the onset of clinical trypanosomosis (17).

There are significant associations between taxonomic groups of wildlife hosts and the prevalence of trypanosomiasis. Wildlife hosts from the bovinae group show a high prevalence of trypanosomiasis, especially $T$. vivax and $T$. congolense as well as human infective T. brucei (Table 1). Infection is attributed to their grazing habits, taking them into contact with tsetse and other biting flies. Wildlife hosts from the Pantherinae group show a very high prevalence of mixed trypanosome infections, as do those from the Suidae (12). A summary of trypanosome species in wildlife hosts and host taxonomy is shown in Table $\mathbf{1 .}$

\section{Transmission to Wildlife}

Transmission of trypanosome species is generally by biting vectors including Tsetse flies, Tabanids, Stomoxys, Heamatopota, and Hippobosca $(15,30,31)$. Infection in carnivores is additionally from consumption of infected meat as documented in the Felidae and Canidae $(31,32)$. Desmodus rotundus (Vampire bats) also transmit trypanosomiasis (32).

Trypanosomes engage in two patterns of transmissions: Cyclical transmission in which trypanosomes undergo active multiplication within the vectors (tsetse flies) as is common for $T$. congolense, T. simiae, T. vivax, T. brucei, and the human infective trypanosome species ( $T$. rhodesiense and T. gambiense); and mechanical transmission through tsetse and alternative vectors including biting flies of the Tabanidae family (horse flies) as well as Stomoxys species. T. evansi and T. vivax can be mechanically transmitted (33).

\section{Distribution of Reservoir Hosts}

Preservation of natural resources including game parks and game reserves has led to an expansion of wildlife populations that serve as reservoirs for AAT and HAT (34). Human encroachment on the game parks and forests has increased AAT transmission between wildlife and domestic livestock, due to increased tsetsehuman and tsetse-livestock contacts (34). The distribution of host populations within these areas determine vector and parasite survival. Wildlife hosts including monkeys and warthogs live in less restrictive habitats, unattractive to poachers with limited trophy hunting leading to increased reservoir host multiplication rates. They are widely distributed in the ecological environment and are favorable reservoirs for multiple trypanosome species due to their availability to vectors. Crocodiles and hippopotamus are limited to specific habitats, limiting access of vectors.

\section{Distribution of Tsetse Flies}

Trypanosomiasis affects one-third of Africa's land mass (35-37). Tsetse are found across most of West, Eastern, Central, and Southern Africa (38). The different species and subspecies of tsetse are shown in Table 2 . Tsetse populations require moderate temperatures $\left(23-25^{\circ} \mathrm{C}\right)$, high relative humidity (75-90\%) with weak saturation deficit and shade (47-49). Temperatures above $34.1^{\circ} \mathrm{C}$ limit survival of tsetse and trypanosomes (35).

\section{Food Source-Activity and Migration}

Differences in wildlife food sources, particularly for wild bovidae, influence their exposure to trypanosomiasis. Among ruminant wildlife hosts, browsers are more at risk of trypanosomiasis compared with grazers; semi-browsers are moderately susceptible. Eland, Waterbuck, Kudu, and Bushbuck are more heavily infected, associated with their preference for inhabiting thickets during tsetse feeding hours, predisposing them to more bites $(13,18)$.

Diurnal wildlife hosts are more susceptible to trypanosome infection compared with the nocturnal species. Warthogs are most active in the morning and late afternoon and show high infection rates for trypanosomiasis in correlation to vector feeding hours (20). Lions are more infected in areas of high tsetse challenge than low challenge (50). The movement of large numbers of animals within wildlife ecosystems also influences infection. Animals will migrate in the dry season toward water sources that are also tsetse habitats (20).

\section{Pathogenesis of Trypanosomosis}

Trypanosome infection leads to erythrophagocytosis and heme catabolism resulting in iron accumulation in tissues and hyperbilirubinemia, liver dysfunction, and multiple organ failure (51). At necropsy, atrophy of body fats, pulmonary edema, hepatomegaly, lymphadenopathy, and hemorrhages are observed. Trypanosomes are found in tissues and body organs, and enlarged periarteriolar sheaths have been observed in wildlife (52).

\section{Clinical Signs}

Trypanosomiasis is a chronic progressive disease, and clinical signs may become obvious in advanced stages of the disease (53). Bovines affected by T. vivax present with severe anemia, lethargy, photophobia, lacrimation, and inappetence $(17,54,55)$; pyrexia fluctuates with the fluctuating parasitemia. Leukopenia, thrombocytopenia, and degenerative and inflammatory lesions are observed in most organs (56). Body condition scores deteriorates gradually, and animals are dehydrated and debilitated before death. Superficial lymph nodes are enlarged and conspicuous. Corneal opacity may be observed with lacrimation (57). Young animals are stunted even with proper feeding, and productivity is impaired by abortions $(32,38)$. Animals may show localized or generalized edema (58). Except for T. equiperdum, other Trypanosoma species include similar clinical signs, but variations in intensity may happen in the various species. Trypanosoma brucei s.l. infection shows limited clinical signs in bovines of indigenous species but is highly pathogenic in exotic species (59).

\section{Diagnosis of Trypanosomiasis}

Trypanosomiasis is characterized by the intermittent presence of parasites in the blood and intermittent fever (54). Parasitological examinations are relatively sensitive during the acute phase 
TABLE 1 | Trypanosome species and taxonomy of wildlife hosts.

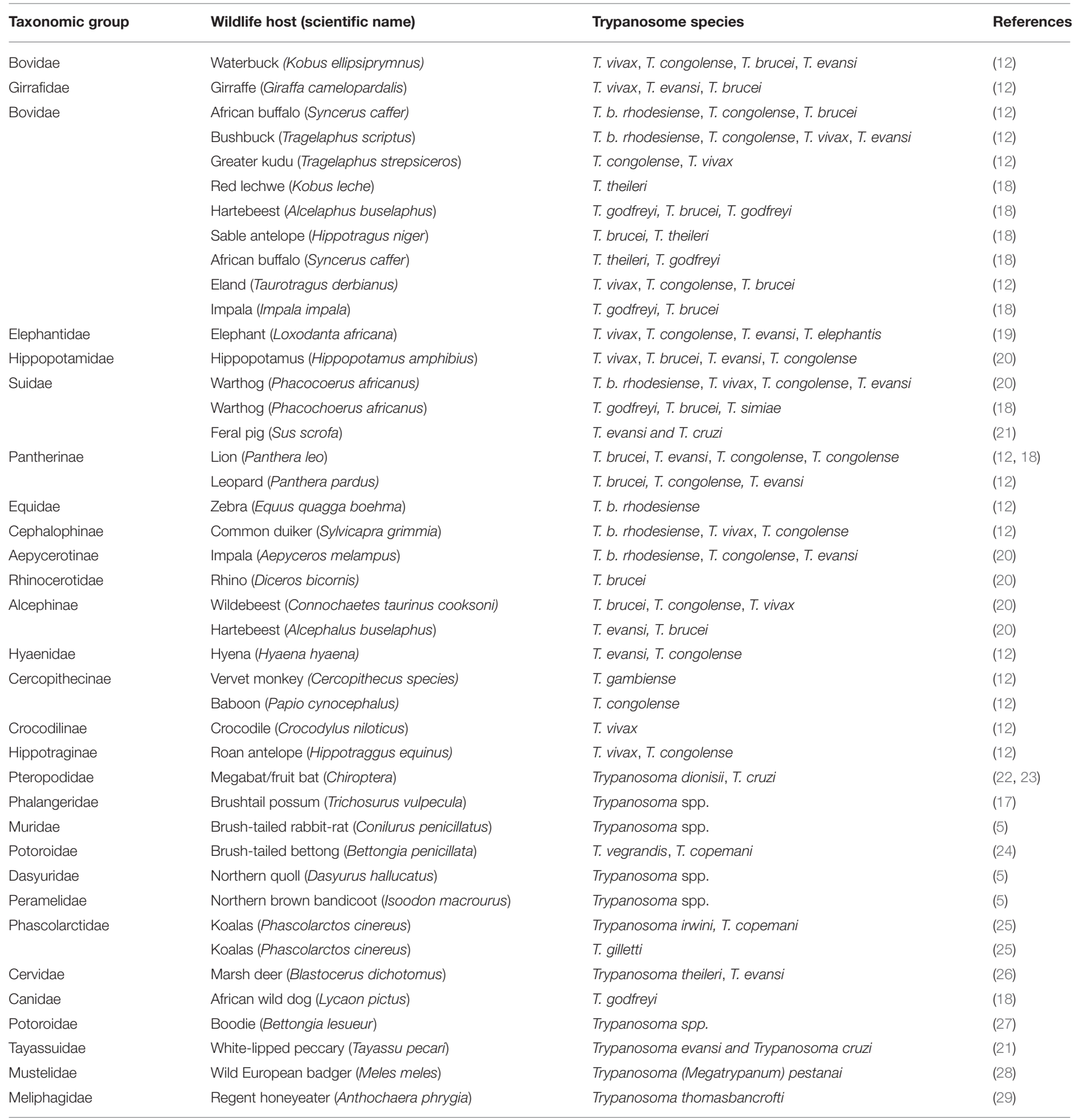

of the disease. Wet blood film examination is used to detect the presence of motile trypomastigotes but has low sensitivity. Blood is taken from the tail or ear veins (55). Fluorescence microscopy can improve sensitivity for thin and thick smears (60). Parasitic concentration by centrifugation and examination of the buffy coat is more sensitive than the wet and thick smears (61). Dark ground or phase-contrast microscopy increases sensitivity at low parasitemia (62). Anion exchange chromatography is also sometimes deployed for detecting low parasitemia $(54,63,64)$.

Molecular tests and serological tests are more sensitive than the usual parasitological tests for Trypanosoma (3, 63-68). Common serological tests include CFT, ELISA, and IFAT, while the common molecular tests are PCR, LOOP/LAMP, and LFA. 
TABLE 2 | Tsetse species, geographical distribution, and wildlife spp. affected by trypanosomiasis.

\begin{tabular}{|c|c|c|c|c|c|}
\hline Subgenus & Glossina species & Glossina subspecies & Country & Wildlife animal spp. & References \\
\hline \multirow[t]{8}{*}{ Nemorrhina (Palpalis) } & Glossina palpalis & G.p.palpalis & Nigeria, Angola Cameroon, & Bushbuck, primates, warthogs & (36) \\
\hline & G. tachinoides & & Nigeria & & (37) \\
\hline & G. fuscipes & G. f. fuscipes & $\begin{array}{l}\text { Uganda, Sudan, Ethiopia, Kenya, } \\
\text { DRC }\end{array}$ & Buffaloes, antelopes & $(41)$ \\
\hline & & G. f. quanzensis & Uganda, Tanzania & Buffaloes, antelopes & (42) \\
\hline & G. pallicera & G. p. pallicera & Cameroon, Ivory coast, Liberia & Antelopes & $(43-45)$ \\
\hline & & G. p. newsteadi & DRC & Lions, leopards & (46) \\
\hline & G. tachinoides & & Nigeria, Ghana, Cameroon & Buffaloes, lions, buffaloes & (46) \\
\hline & G. caliginea & & Nigeria, Congo Brazaville & Cheetah, lions, leopards & (46) \\
\hline & G. swynnertoni & & Nigeria, Congo Brazaville & Lions, cheetahs & (46) \\
\hline & G. longipalpis & & Ivory Coast, Senegal, Mali & Buffaloes, lions & (46) \\
\hline & G. pallipides & & $\begin{array}{l}\text { Ethiopia, DRC, Uganda, Kenya, } \\
\text { Zambia, Tanzania }\end{array}$ & Buffaloes, lions, antelopes & (46) \\
\hline & G. austeni & & Kenya, Tanzania, Mozambique & Bushbucks, antelopes, lions & (46) \\
\hline & G. vanhoofi & & DRC & Lions & (46) \\
\hline & G. tabanformis & & Nigeria, DRC & Buffaloes, lions & (46) \\
\hline & G. severini & & DRC & Lions, bushbucks & (46) \\
\hline & G. schwetzi & & Togo. Congo Brazaville & Wild ruminants & (46) \\
\hline & G. nigrofusca & & Ivory Coast, Nigeria, CAR, DRC & Elephants, lions, monkeys & (46) \\
\hline & G. nashi & & Cameroon, Nigeria, Togo & Monkeys, baboons, wild cats & (46) \\
\hline
\end{tabular}

Low-flow assay (LFA) is cheaper with $96.3 \%$ sensitivity and $93.9 \%$ specificity (69). Approved tests for AAT are shown in Table 3.

\section{TRYPANOSOMES IN WILDLIFE}

The majority of trypanosome species require multiple obligatory hosts to complete their life cycles (heteroxenous), and the transmission of the parasites is mainly via hematophagous invertebrate vectors $(2,88)$. Trypanosomes are found in blood and tissues; blood-borne protozoan trypanosomes (Trypanosoma vegrandis) have been identified in wild animals including, but not limited to, the northern brown bandicoot (Isoodon macrourus), common brushtail possum (Trichosurus vulpecula), northern quoll (Dasyurus hallucatus), and brush-tailed rabbitrat (Conilurus penicillatus) (5). Trypanosoma cruzi, Trypanosoma dionisii, and an insect trypanosome (Blastocrithidia) have been found to infect bats and other mammalian wildlife in Europe and South America (22). Bats, possums, and rats act as reservoirs of trypanosomes for domestic and wild animals, as well as humans $(5,22)$. T. cruzi (Chagas) has been identified in kidney tissue, heart muscle, and blood, urine, and peritoneal fluid of wild spp. including foxes, opossums, raccoons, and striped skunks $(89,90)$, and parasites can be transmitted from animal-to-animal by contamination of animal wounds with blood, urine, and peritoneal fluid $(89,90)$.

\section{Trypanosome-Host Relationships}

Hosts are classified according to their role as a definitive host [if the mature sexual stage(s) of the parasite occurs within them] or intermediate hosts when the more mature sexual stages of the parasite only aid part of the life cycle (91). Transfer (paratenic) hosts are not vital for the completion of parasitic development cycles but maintain the parasite before it reaches the obligatory/definitive host $(92,93)$. Invertebrates (vectors) acting as hosts and carriers of parasites facilitate the completion of parasitic life cycles by transmitting parasites (94-96).

Trypanosomes can infect many hosts, transmitted by hematophagous insect vectors mainly the tsetse fly and triatomid kissing bugs (subfamily: Reduviidae) (13, 97). Salivarian trypanosomes, Trypanosoma brucei, T. rhodesiense, 
TABLE 3 | Approved laboratory tests for trypanosomiasis according to OIE (70).

\begin{tabular}{|c|c|c|c|}
\hline Test criteria & Objective & Methods & References \\
\hline Clinical signs & $\begin{array}{l}\text { Categorize } \\
\text { presentation }\end{array}$ & Observations & $(32,53,71)$ \\
\hline \multirow[t]{7}{*}{ Microscopy } & $\begin{array}{l}\text { Direct } \\
\text { examination }\end{array}$ & Wet blood films & (72) \\
\hline & & Thick blood films & $(60,61)$ \\
\hline & & Thin blood smear films & (72) \\
\hline & $\begin{array}{l}\text { Parasitic } \\
\text { concentration }\end{array}$ & $\begin{array}{l}\text { Microhematocrit } \\
\text { centrifugation } \\
\text { technique }\end{array}$ & (61) \\
\hline & & $\begin{array}{l}\text { Dark ground or } \\
\text { phase-contrast buffy } \\
\text { coat technique }\end{array}$ & (62) \\
\hline & & $\begin{array}{l}\text { Anion exchange } \\
\text { technique }\end{array}$ & $(73-75)$ \\
\hline & $\begin{array}{l}\text { Cultivation } \\
\text { technique }\end{array}$ & Animal inoculation & (76-78) \\
\hline \multirow[t]{5}{*}{$\begin{array}{l}\text { Molecular } \\
\text { detection }\end{array}$} & Antigen assays & $\begin{array}{l}\text { Trypanosome antigen } \\
\text { detection assays }\end{array}$ & (79) \\
\hline & $\begin{array}{l}\text { Trypanosome } \\
\text { DNA }\end{array}$ & Monospecific PCR & (80) \\
\hline & & Multi-specific PCR & $(81,82)$ \\
\hline & & LOOP & (68) \\
\hline & & LFA & $(69,83)$ \\
\hline \multirow[t]{3}{*}{ Serology } & Antibodies & $\begin{array}{l}\text { Indirect } \\
\text { immunofluorescence } \\
\text { test }\end{array}$ & (84) \\
\hline & & IgG antibody ELISA & (85) \\
\hline & & IgG antibody detection & $(86,87)$ \\
\hline
\end{tabular}

T. equiperdum, T. vivax, and T. congolense are transmitted in tsetse fly (Glossina spp.) saliva to the host spp. Hosts are as follows: T. brucei s.l. (domestic mammals and humans), T. vivax (ruminants, horses, and camels), T. equiperdum (equines), $T$. simiae (pigs), and T. congolense (dogs and cats) causing T. evansi (domestic mammals), and other numerous wildlife hosts such as monkeys, guinea pigs, rabbits, rats, etc., are also affected $(91,98)$. Stercorian trypanosomes are transmitted through the fecal matter of the insects (Triatominae, e.g., Triatoma infestans) to host skin where they gain access to tissues. Other vectors of transmission for stercorians include Tabanid flies, stable flies, ticks, and mosquitoes. Stercorians include Trypanosoma cruzi, T. lewisi, T. melophagium, T. nabiasi, T. rangeli, T. theileri, T. theodori, T. lewisi, T. cruzi, bat spp. (Trypanosoma cruzi marinkellei, Trypanosoma dionisii, Trypanosoma erneyi, Trypanosoma livingstonei, and Trypanosoma wauwau), and others: Trypanosoma conorhini and Trypanosoma rangeli $(94,95,98,99)$. Among wildlife, T. cruzi is found in armadillos, dogs, possums, foxes, bats, raccoons, and striped skunks $(5,22,89,90)$. In addition, T. melophagum and T. theileri are found in Europe infecting cattle, buffaloes, and antelopes (98).

\section{Trypanotolerance}

Trypanotolerant animals show a few clinical signs $(96,97)$, and trypanosomes are able to evade the host immune responses (100). Trypomastigotes penetrate a variety of host cell types and multiply intracellularly as amastigotes-which eventually infect host cells and differentiate into BFT, which eventually invade the lymphatic and circulatory systems $(50,101)$. Trypanosoma cell membranes are covered with dense variable surface glycoprotein (VSG) homodimers-immunodominant antigens that trigger infected host B- and Th-cell-mediated immune responses. Over 1,000 different VSG genes and pseudogenes are present in the trypanosome genome that can undergo segmental gene recombination to encode an estimated 10,000 different VSG surface coats. High antigenic variability in VSG molecules hinders vaccine development (102).

Wildlife, while generally immunotolerant to trypanosomes (103) can, however, develop clinical trypanosomiasis (104) and show varying levels of trypanotolerance among species (105, 106). Trypanotolerance is influenced by multiple host intrinsic and extrinsic factors and can develop from previous exposure (106). Intrinsic factors include age, sex, species, physiological state, and state of nutrition, while extrinsic factors include temperature, humidity, nature of vegetation, and the nature of wildlife communities (107).

A study in the Serengeti National Park, Tanzania, showed agedependent infection with T. congolense in lions (Panthera leo); however, the same animals appeared to have developed crossimmunity following infections to multiple trypanosome species including T. brucei rhodesiense (101). Lions are exposed to high challenge from trypanosomes, both from tsetse and also from infected prey, becoming exposed to extremely high numbers of VSGs. This work suggests that animals within a closed exosystem can control infections and, in this case, eliminate the human infective parasite $T . b$. rhodesiense from the infection pool.

\section{Development of Resistance}

Trypanotolerance can enable the regulation of parasite levels in the blood (parasitemia) and body tissues. Resistance in wildlife species has been associated with serum xanthine oxidase and catalase and other trypanolytic molecules $(108,109)$. Stress can affect trypanotolerance in wildlife (71). Trypanotolerance has been investigated in mice and cattle, although these have differences in immune response, i.e., more pronounced B-cell activation in mice than in cattle (50). In cattle, antibody (IgG and $\operatorname{IgM}$ ) and complement activity against parasitic VSGs leads to protection (110), through antigenic neutralization and IL-4 production (111) (Figure 1).

In Cape buffalo, resistance has been associated with nonspecific trypanocidal activity in serum, which helps to lower the parasitemia following action of xanthine oxidase (XO), which generates reactive oxygen species (ROS). Since trypanosomes cannot metabolize $\mathrm{XO}$, this cripples parasitic binding and endocytosis (111), trypanosomes are starved of ATP, and death follows (Figure 1). An increase in catalase activity is associated with increased parasitemia (112). Some wildlife spp. including the black rhinoceros have significant deficiencies for ATP, catalase, and glycolysis enzymes (conditions that favor trypanosome parasitemia) leading to adaptive evolutionary changes, which help to protect the animals against the parasites (113). 


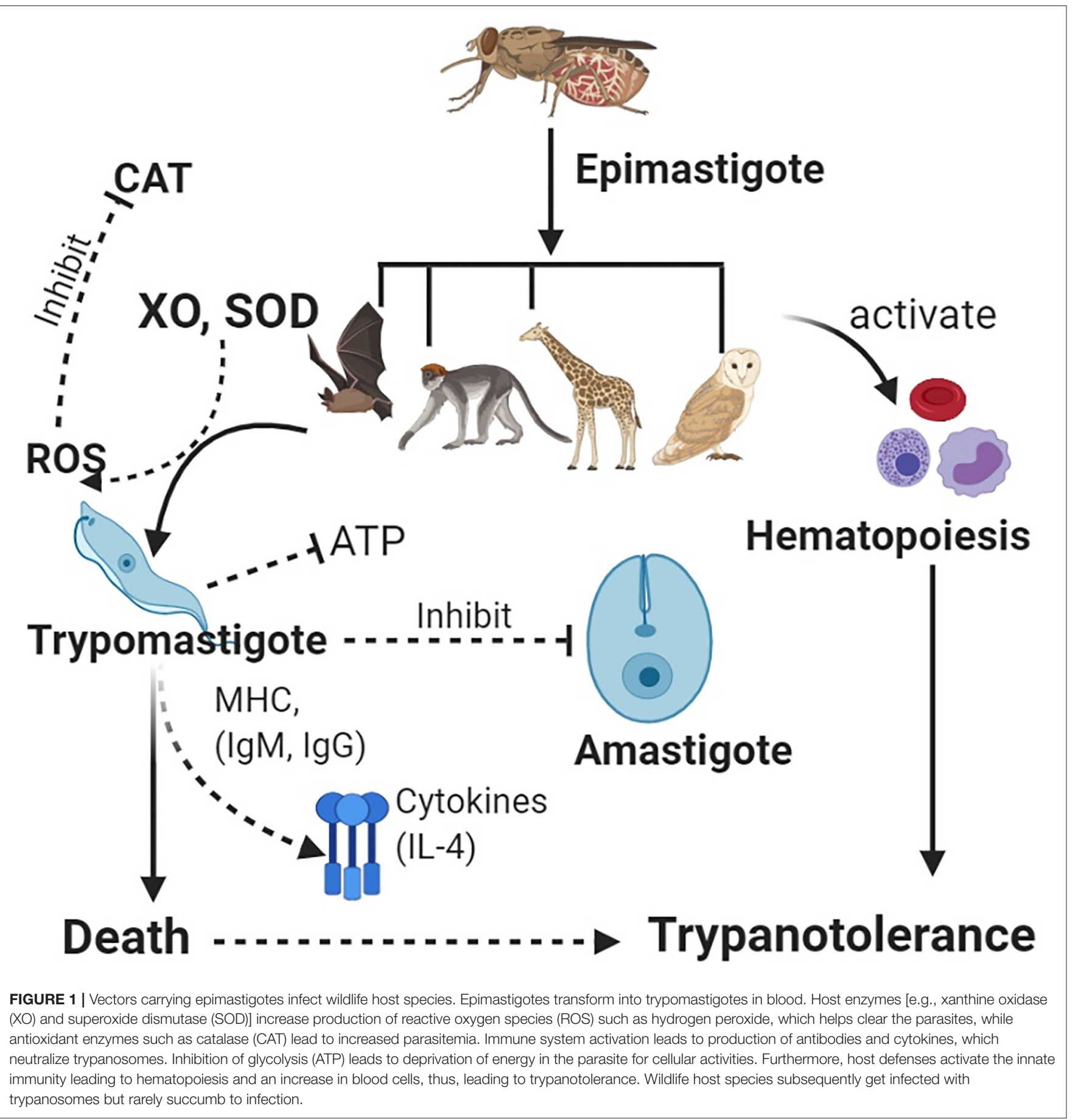

Wild animals show varying levels of trypanotolerance; the Thomson's gazelle, dikdik, blue forest duiker, jackal, bat-eared fox, ant bear, hyrax, serval, and monkey are all susceptible to T. rhodesiense and T. brucei, whereas the common duiker, eland, bohor reedbuck, spotted hyena, oribi, bushbuck, impala, warthog, bushpig, porcupine, and baboon are considered resistant (or less susceptible) to T. b. rhodesiense and T. brucei infection $(114,115)$. Animals most susceptible are usually found in areas of high tsetse challenge, while those least susceptible (resistant) animals within the population may have acquired resistance through low exposure and challenge over time (116).

The clinical course of trypanosomiasis has been examined in native African buffalo (Syncerus caffer), oryxes (Oryx beisa), eland (Taurotragus oryx), and waterbuck (Kobus defassa) following infection with $T$. congolense, $T$. vivax, or $T$. brucei. These animals showed resistance in the form of negligible parasitemia 
and minimal anemia (115). Wild and domestic animals have been observed to develop resistance to trypanosomiasis after being subjected to prolonged continuous trypanosome infections $(117,118)$, and as previously mentioned, indigenous bovines are resistant to T. brucei within endemic foci in Uganda $(114,115)$.

\section{TRYPANOSOMIASIS AT THE WILDLIFE, DOMESTIC ANIMAL INTERFACE}

\section{Diversity of Trypanosomes in Wildlife}

Multiple Trypanosoma species and genotypes contribute to a large reservoir of parasite diversity. This presents major problems in the management of trypanosomiasis at the wildlife-domestic animal interface, with the risk of virulent strains emerging that impact both wildlife and domestic populations (5). A review of Australian animal trypanosomes found a huge variety of parasites: T. pteropi, T. thylacis, T. hipposideri, T. binneyi, T. irwini, T. copemani, T. gilletti, T. vegrandis, T. lewisi, T. melophagium, T. theileri, T. nabiasi, T. evansi, T. cruzi, T. pteropi, T. hipposideri, T. binneyi, T. thylacis, T. copemani, T. Irwin, and T. gilleti. Such biodiversity may have negative impacts on the wildlife and national parks, and is associated with biosecurity concerns $(88,119)$. Newly identified genotypes of wildlife animals include Trypanosoma vegrandis $G 6$ and T. vegrandis G3 (5). Furthermore, a study in bats found three Trypanosoma spp. (T. cruzi, T. dionisii, and Blastocrithidia spp.) (22) demonstrating the great diversity in several wildlife species.

\section{Infection at the Wildlife, Domestic Animal Interface}

Climate change, population pressure, and incentives to end poverty through farming have forced humans to encroach into land previously occupied by wildlife $(108,120)$. Human encroachment in protected zones runs the risk of parasite transmission from wildlife to domestic animals and zoonotic transmission $(108,109,121)$. Synanthropic zoonotic infections are spread from livestock to humans, and exoanthropic infections are spread by wildlife and feral animals to humans-contributing to the increasing gene pool of anthroponoses (98). The crossspecies (interspecies) transmission, also known as host jump or spillover, means the potential of an external parasite to invade a new host and infect them to ultimately spread to the whole population of the new host. About $63 \%$ of host jumps are responsible for interspecies diseases $(109,122,123)$.

Endemic zones are created by encroaching on places of game parks. This has caused a wildlife and livestock interface, and development of the trypanosome parasite reservoirs (117). Wildlife is often implicated as the reservoir of parasites especially trypanosomes $(37,124,125)$. It is common for the high incidences of trypanosomiasis in the wildlife to spillover to the domestic cycle in the tsetse fly-infested zones (71). Domestic animals pose a risk to wildlife, particularly the great apes, especially if the domestic carriers are present, for example, cattle and dogs (32).
Infection with $T . b$. rhodesiense is common in communities living proximal to, or that are dependent on, wildlife or ecotourism $(126,127)$. In the Luangwa Valley, Zambia, considerable efforts are made to keep domestic animals away from the national park, for biosecurity of livestock keepers, the national parks, and game conservancies (128). In Zambia, HAT infections have been associated with young children attending school and older women demonstrating in the homestead $(129,130)$.

A study in Australia failed to find T. cruzi and T. evansi in native domestic and wildlife animals; however, a spillover for exotic Trypanosoma spp. was expected that would affect humans, domestic, and wild animals (88). Wildlife (Clyomys laticeps, Thrichomys pachyurus, and Oecomys mamorae) can be reservoir hosts for Trypanosoma spp., e.g., T. evansi and T. cruzi that could infect humans and other wildlife populations without affecting the rodent spp. (131).

\section{Factors That Could Influence Trypanosomiasis Epidemiology in Wildlife Areas}

Host species that are widely distributed and with fewer restrictions on habitat have proved to be of more importance to trypanosome diversity due to their unlimited breeding potential and less risk for poaching and trophy hunting. Such hosts include warthogs, bushbucks, kudus, buffaloes, and giraffes (20). More habitat-restricted host species have minimal contribution to the epidemiology of trypanosomiasis in wildlife communities due to their relative safety from trypanosome vectors like Glossina and Tabanids, e.g., crocodiles and hippopotamus.

Differences in feeding patterns of the trypanosome hosts influence the distribution of trypanosomiasis in wildlife areas. Certain preferences maintained by certain hosts like bovines (bushbuck, waterbuck, eland, kudu, etc.) to bushy areas and thickets have predisposed them to higher exposure rates to tsetse and other biting flies, intensifying the spread of trypanosomes (20). Trypanosome diversity among the host species has facilitated the cross-transmission of various trypanosome strains and variants among the hosts, increasing infection rates among wildlife communities at both clinical and subclinical levels. For example, the discovery of three different variants of T. vivax in three different host species including a buffalo, a waterbuck, and a giraffe not similar to any published strain, demonstrating genetic diversity, provides insights on pathogen epidemiology (3).

Furthermore, the introduction of new host species from a different geographical location into a wildlife reserve can greatly influence the trypanosome species diversity in a wildlife community. This way, new variants and species of trypanosomes are spread from one host to another by tsetse and other biting flies, resulting in devastating effects on wildlife health and livestock health in the area, for example, the discovery of $T$. melophagium, T. nabasi, T. theieri, and $T$. evansi in Australia following the introduction of various mammals into their wildlife populations, which had a great impact on the native marsupials (9) 


\section{Wildlife Encroachment and the Epidemiology of Trypanosomiasis}

Encroachment to wildlife and the increasing human and livestock density as well as the altered patterns in land use are key parameters that govern the transmission of trypanosomes (132). It is expected that understanding how the encroachment to wildlife affects the epidemiology of trypanosomes will inspire practical approaches to improve the understanding of epidemiological characteristics of trypanosome transmission in the context of ecological factors. Encroachment to wilderness areas of Africa increases the epidemiology of trypanosomes, hence, increasing the transmission of HAT. Primarily, wildlife are trypanosome reservoirs; however, growing human and livestock numbers around or in wildlife areas increase the significance of livestock in the transmission cycles thereby increasing the epidemiology of trypanosomes pertinent to human health (132).

Understanding undercurrents associated with the transmission of trypanosomes and in relationship with the encroachment of livestock and humans to wildlife areas are vital to developing robust control measures. This would help identify important parameters on host distributions, tsetse populations, epidemiology of trypanosomes, infection and mortality rates, the significance of livestock, humans, and livestock as hosts in wildlife areas, hence, promoting the progress of models to help in the evaluation and application of control measures (132). Parameters that determine the dynamics in encroachment levels to wildlife areas such as protected area, wildlife density, livestock density, human density, and location according to space and time, would help determine the foci of HAT. This is important since increased human and livestock populations and their distribution may lead to land-use pattern changes in fragmented tsetse habitats, and this inevitably affects the distribution of wildlife species. These ultimately result in increased tsetse abundance and distribution, host selection, and tsetse mortality, which are indicators of increased vector competence (132). Host population density is a key factor in determining the dynamics of tsetse populations, i.e., a decline in host density through encroachment to wildlife areas influences tsetse population changes in space and time. This, in turn, influences the transmission of trypanosomes, and although low host density decreases trypanosome transmission as a consequence of tsetse mortality, the low host density may also be associated with an increased level of trypanosome transmission arising from the hungrier flies that bite humans through increased host-seeking efficiency of tsetse flies (133).

\section{INFECTION CONTROL AT THE WILDLIFE-LIVESTOCK-HUMAN INTERFACE}

While communities fail to understand the value of wildlife ecosystems, continued wildlife-human conflict presents an increased risk of infection spillover to humans (18, 118, 134, 135). Game parks, the natural habitats for tsetse species, pose risks to livestock and human populations (136, 137), and parasitic infestations among the livestock and humans equally pose a risk to wildlife. Wildlife reservoirs make approaches of trypanosomosis control at the wildlife-livestock-human interface more complicated $(30,31)$. There is a need to limit the interaction between livestock and wildlife by preventing encroachment into wildlife-protected zones. Mitigation of risk to prevent trypanosome (and other) infections circulating among livestock and wildlife demands a holistic One Health approach (108, 138, 139). Top-down, approaches, shooting games and radical bush clearing, and insecticide spraying in protected zones are neither practical nor acceptable (140). Stakeholder and community-derived solutions are likely to be sustainable options to explore. Approaches to infection control require to be nuanced in these zones, with communication, education, and interventions embedded within the affected communities. Integrated insect control approaches including the use of insecticide-impregnated targets can protect livestock and game (141). Application of insecticides to cattle, using livestock as live baits, can offer sustainable solutions (138, 142, 143); however, challenges remain on the sustainability of this approach especially in low-middle income countries (LMICs). Insecticides are a reliable method for tsetse control and can be improved by deploying an integrated insecticide approach $(139,141)$. Routine prophylaxis among livestock can protect livestock and offer collateral benefits for humans and wildlife $(144,145)$. There is also a need to limit the interaction between livestock and wildlife by stopping encroaching on gazetted wildlife zones to lower the trypanosome prevalence in domesticated livestock (108).

Animal and Human Health for the Environment and Development (AHEAD), launched in 2003, comprises a One Health team of socioeconomic scientists, ecobiologists, veterinarians, agriculturalists, wildlife, and public health specialists that address issues at the wildlife, human, and domestic livestock interface. This includes efforts to monitor parasitic diversity in wildlife species to assist in the strengthening of disease surveillance in LMICs (146). Management and communication with regard to wildlife is key to the One Health approach; in pastoral communities, retaliatory persecution through poisonings of predatory wildlife continues to challenge conservation efforts (147). Conflicts associated with competition for natural resources between livestock-keeping communities and wildlife can be mitigated by a combination of communication and control strategies to promote peaceful coexistence of wildlife and humans as promoted by AHEAD.

\section{Management of Spillover of Trypanosomiasis Among the Human-Wildlife Areas}

Communities in the wildlife zones sometimes agree on coexistence with wildlife and the creation of buffer zones (148). However, the coexistence of human communities and wildlife poses risks of outbreaks of various zoonoses (149). In the gazetted wildlife zones, there should be no mixing of domestic animals with wild trypanosomiasis reservoirs. Proper fencing can be used to control the spillover in wildlife borders (150) as part of the integrated trypanosomiasis control strategy. Restrictive models need to be developed by engaging the communities 
such that they understand these objectives (151). There is a need for legislation on fencing to have restricted movement of livestock and wildlife. The laws need to address the challenges of wildlife biodiversity (152) and penalize encroachers and poachers. This requires an appropriate land tenure system and robust enforcement teams.

Renowned trypanosome hosts like bats need to be removed from urban centers and human dwellings. Bats also live in human dwellings in ceilings and other dark points. African bats are hosts of trypanosomes (153). It is not known whether the African bats are associated with virulent chronic and acute human African trypanosomiasis. However, bats are associated with trypanosomes in central and South America $(22,154,155)$.

Research on possible vaccine candidates has not broken through despite emphasis on the VSG pathway $(102,156)$. This, however, does not translate that research on trypanosome vaccines has reached a dead end since in all the failures, better innovations can transform science to improve understanding in this field $(157,158)$. This is important since drugs that are used to treat domestic animals have been used to treat wildlife with success $(159,160)$, although this has not been done against infections with the zoonotic trypanosomes.

Wildlife are usually in contact with insects other than the tsetse flies. It is known that lice can transmit $T$. cruzi (161). The possibility of lice transmitting the zoonotic trypanosomes is not known. Zoonotic trypanosomes have been found in fleas (162), and it is speculated that fleas may transmit trypanosomes among wildlife (163-165). The possible transmission of trypanosomes by other biting arthropods among wildlife needs further investigation. The possibility of transmission along the food chains for carnivores needs further investigation. Wild Canidae that feed on fresh blood from trypanosomiasis reservoirs may acquire infections from the fresh blood. No studies have ever been proposed among atrisk carnivores.

There is a need to study the interactions of trypanosomes with other blood parasites. Trypanosomes interact with babesia especially to worsen the stress conditions of translocation (166-168). The effect of trypanosomes on the immune system likely predisposes the animals to opportunistic infections and tick-borne diseases. The presence of other parasites is possibly a contributing factor to the trypanosomiasis spillover.

\section{REFERENCES}

1. World Health Organization. Tropical Disease Research: Progress 197594, Highlights 1993-94, Twelfth Programme Report of the UNDP/World Bank/WHO Special Programme for Research and Training in Tropical Diseases (TDR). Geneva: World Health Organization (1995). Available online at: https://www.who.int/tdr/publications/progress-75-94/en/

2. Thompson RCA. Parasite zoonoses and wildlife: one health, spillover and human activity. Int $J$ Parasitol. (2013) 43:1079-88. doi: 10.1016/j.ijpara.2013.06.007

3. Auty $\mathrm{H}$, Anderson NE, Picozzi K, Lembo T, Mubanga J, Hoare R, et al. Trypanosome diversity in wildlife species from the serengeti and luangwa valley ecosystems. PLoS Negl Trop Dis. (2012) 6:e1828. doi: 10.1371/journal.pntd.0001828

\section{CONCLUSION}

Trypanosomiasis continues to be a major global challenge, particularly so at the wildlife-domestic livestock interface. Multiple wildlife species serve as maintenance hosts promoting infections at the livestock-wildlife interface. There is a high risk of infection spillover from game parks and conservation areas where parasites and vectors are concentrated in high numbers, and domestic livestock pose risks to wildlife-protected species. The basis of trypanotolerance in wildlife species is not well-understood. The wide genetic diversity exhibited by Trypanosoma spp. is a challenge, both exacerbating the risk of increased virulence and making the development of a vaccine unlikely. One Health strategies that are community and environmentally friendly are needed to support stakeholders to mitigate risk. There is a need to strengthen trypanosomiasis research, particularly in LMICs, especially at the humandomestic-wildlife interface to prevent cross-species infection.

\section{AUTHOR CONTRIBUTIONS}

KIK and SCW conceptualized the study, designed the study, and analyzed and interpreted the data. KIK, GZ, FS, BB, KJA, KM, HNN, LA, DO, PB, JJO, SI, WM, DPN, GESB, LOO, TS, MA, LO, and SCW collected the data. KIK wrote initial draft while SCW critically reviewed it for intellectual content. All authors approved the manuscript for publication and remain in agreement on all aspects of the work.

\section{FUNDING}

This research was supported by the National Institute for Health Research (NIHR) Global Health Research programme $(16 / 136 / 33)$ using UK aid from the UK Government. The views expressed in this publication are those of the author(s) and not necessarily those of the NIHR or the Department of Health and Social Care (SCW/KIK/TS). This work was also supported by Zhejiang University Education Foundation Emergency Research Fund (SCW, TS, and KIK), Global Challenges Research Fund, and the University of Edinburgh (SCW/TS/KIK), and Taif University Researchers Supporting Program (project number: TURSP-2020/128), Taif University, Saudi Arabia.
4. Franck SA. Models of parasite virulence. Q Rev Biol. (1996) 71:37-78. doi: $10.1086 / 419267$

5. Barbosa A, Reiss A, Jackson B, Warren K, Paparini A, Gillespie G, et al. Prevalence, genetic diversity and potential clinical impact of blood-borne and enteric protozoan parasites in native mammals from northern Australia. Vet Parasitol. (2017) 238:94-105. doi: 10.1016/j.vetpar.2017.04.007

6. Desquesnes M, Holzmuller P, Lai D-H, Dargantes A, Lun Z-R, Jittaplapong S. Trypanosoma evansi and Surra: a review and perspectives on origin, history, distribution, taxonomy, morphology, hosts, and pathogenic effects. Biomed Res Int. (2013) 2013:1-22. doi: 10.1155/2013/194176

7. Barros JHS, Xavier SCC, Bilac D, Lima VS, Dario MA, Jansen AM. Identification of novel mammalian hosts and Brazilian biome geographic distribution of Trypanosoma cruzi TcIII and TcIV. Acta Trop. (2017) 2017:3. doi: 10.1016/j.actatropica.2017.05.003 
8. Osório ALAR, Madruga CR, Desquesnes M, Soares CO, Ribeiro LRR, Costa SCG da. Trypanosoma (Duttonella) vivax: its biology, epidemiology, pathogenesis, and introduction in the New World - a review. Mem Inst Oswaldo Cruz. (2008) 103:1-13. doi: 10.1590/S0074-02762008000100001

9. Aregawi WG, Agga GE, Abdi RD, Büscher P. Systematic review and meta-analysis on the global distribution, host range, and prevalence of Trypanosoma evansi. Parasites Vectors. (2019) 12:4. doi: 10.1186/s13071-019-3311-4

10. Büscher P, Gonzatti MI, Hébert L, Inoue N, Pascucci I, Schnaufer A, et al. Equine trypanosomosis: enigmas and diagnostic challenges. Parasites Vectors. (2019) 12:19. doi: 10.1186/s13071-019-3484-x

11. Geiger A, Malele I, Abd-Alla AM, Njiokou F. Blood feeding tsetse flies as hosts and vectors of mammals-pre-adapted African Trypanosoma: current and expected research directions. BMC Microbiol. (2018) 18:162. doi: 10.1186/s12866-018-1281-x

12. Anderson NE, Mubanga J, Fevre EM, Picozzi K, Eisler MC, Thomas R, et al. Characterisation of the wildlife reservoir community for human and animal trypanosomiasis in the Luangwa Valley, Zambia. PLoS Negl Trop Dis. (2011) 5:e1211. doi: 10.1371/journal.pntd.0001211

13. Bengis RG, Kock RA, Fischer J. Infectious animal diseases: the wildlife / livestock interface Wildlife-maintained (indigenous) diseases. Rev Sci Tech. (2002) 21:53-65. doi: 10.20506/rst.21.1.1322

14. Mbaya AW, Ahmad T, Igbokwe I. Current survey of trypanosomosis among livestock and wildlife in the arid region of Northeastern, Nigeria. Bull Anim Hlth Prod Afr. (2013) 61:323-30. Available online at: https://www.ajol.info/ index.php/bahpa/article/view/105265

15. Rahman AH, Ibtisam AG, Rihab AY, Salma AR, Gasmir G. The effect of bovine trypanosomosis and endo-parasitism on milk production of a dairy farm in The White Nile State, Sudan. Sudan J Vet Res. (2008) 23:19-27. Available online at: http://sudanjvr.net/journal/11.pdf

16. Obanda V, Kagira JM, Chege S, Okita-Ouma B, Gakuya F. Trypanosomosis and other co-infections in translocated black (Diceros bicornis michaeli) and white (Ceratotherium simum simum) rhinoceroses in Kenya. Sci Parasitolo. (2011) 12:103-7. Available online at: http://www.zooparaz.net/scientia/ 2011_12_02/sp2011-103-107-vincent.pdf

17. Gupta MP, Kumar H, Singla LD. Trypanosomosis concurrent to tuberculosis in black bucks. Indian Vet J. (2009) 86:727-8. Available online at: https:// www.cabdirect.org/cabdirect/abstract/20093214671

18. Squarre D, Hayashida K, Gaithuma A, Chambaro H, Kawai N, Moonga L, et al. Diversity of trypanosomes in wildlife of the Kafue ecosystem, Zambia. Int J Parasitol Parasites Wildl. (2020) 12:34-41. doi: 10.1016/j.ijppaw.2020.04.005

19. Bruce CD, Hamerton AE, Bateman HR, Mackie FP. A note on the occurrence of a Trypanosome in the African Elephant. $R$ Soc. (1908) 12:414-7.

20. Munang'andu HM, Siamudaala V, Munyeme M, Nalubamba KS. A review of ecological factors associated with the epidemiology of wildlife trypanosomiasis in the Luangwa and Zambezi valley ecosystems of Zambia. Interdiscip Perspect Infect Dis. (2012) 2012:1-13. doi: 10.1155/2012/ 372523

21. Herrera HM, Abreu UGP, Keuroghlian A, Freitas TP, Jansen AM. The role played by sympatric collared peccary (Tayassu tajacu), white-lipped peccary (Tayassu pecari), and feral pig (Sus scrofa) as maintenance hosts for Trypanosoma evansi and Trypanosoma cruzi in a sylvatic area of Brazil. Parasitol Res. (2008) 103:619-24. doi: 10.1007/s00436-008-1021-5

22. Hodo CL, Goodwin CC, Mayes BC, Mariscal JA, Waldrup KA, Hamer SA. Trypanosome species, including Trypanosoma cruzi, in sylvatic and peridomestic bats of Texas, USA. Acta Trop. (2016) 164:259-66. doi: 10.1016/j.actatropica.2016.09.013

23. Clément L, Dietrich M, Markotter W, Fasel NJ, Monadjem A, López-Baucells A, et al. Out of Africa: the origins of the protozoan blood parasites of the Trypanosoma cruzi clade found in bats from Africa. Mol Phylogenet Evol. (2020) 145:106705. doi: 10.1016/j.ympev.2019.106705

24. Thompson CK, Wayne AF, Godfrey SS, Thompson RCA. Temporal and spatial dynamics of trypanosomes infecting the brush-tailed bettong (Bettongia penicillata): a cautionary note of disease-induced population decline. Parasites Vectors. (2014) 7:1-11. doi: 10.1186/1756-33057-169
25. McInnes LM, Gillett A, Hanger J, Reid SA, Ryan UM. The potential impact of native Australian trypanosome infections on the health of koalas (Phascolarctos cinereus). Parasitology. (2011) 138:873-83. doi: 10.1017/S0031182011000369

26. Orozco MM, Argibay HD, Minatel L, Guillemi EC, Berra Y, Schapira A, et al. A participatory surveillance of marsh deer (Blastocerus dichotomus) morbidity and mortality in Argentina: first results. BMC Vet Res. (2020) 16:321. doi: 10.1186/s12917-020-02533-x

27. Averis S, Thompson RCA, Lymbery AJ, Wayne AF, Morris KD, Smith A. The diversity, distribution and host-parasite associations of trypanosomes in Western Australian wildlife. Parasitology. (2009) 136:126979. doi: 10.1017/S0031182009990801

28. Ideozu EJ, Whiteoak AM, Tomlinson AJ, Robertson A, Delahay RJ, Hide G. High prevalence of trypanosomes in European badgers detected using ITS-PCR. Parasites Vectors. (2015) 8:4-9. doi: 10.1186/s13071-015-1088-7

29. Šlapeta J, Morin-Adeline V, Thompson P, McDonell D, Shiels M, Gilchrist $\mathrm{K}$, et al. Intercontinental distribution of a new trypanosome species from Australian endemic Regent Honeyeater (Anthochaera phrygia). Parasitology. (2016) 143:1012-25. doi: 10.1017/S0031182016000329

30. Diall O, Cecchi G, Wanda G, Argilés-Herrero R, Vreysen MJB, Cattoli G, et al. Developing a progressive control pathway for African animal trypanosomosis. Trends Parasitol. (2017) 33:499-509. doi: 10.1016/j.pt.2017.02.005

31. Musinguzi SP, Suganuma K, Asada M, Laohasinnarong D, Sivakumar T, Yokoyama N, et al. A PCR-based survey of animal African trypanosomosis and selected piroplasm parasites of cattle and goats in Zambia. J Vet Med Sci. (2016) 78:1819-24. doi: 10.1292/jvms.16-0240

32. Silva R, Barros A, Herrera H. Trypanosomosis outbreaks due to Trypanosoma evansi in the Pantanal, Brazil. A preliminary approach on risk factors. Rev Elev Med Vet Pays Trop. (1995) 48:315-9. doi: 10.19182/remvt.9432

33. Finelle P. African animal trypanosomiasis. In: World Animal Review. Rome: Food and Agriculture Organization of the United Nations (1983). p. 5. Available online at: http://www.fao.org/3/ah809e/AH809E00.htm\#Contents

34. Mulenga GM, Henning L, Chilongo K, Mubamba C, Namangala B, Gummow B. Insights into the control and management of human and bovine african trypanosomiasis in Zambia between 2009 and 2019 - a review. Trop Med Infect Dis. (2019) 5:115. doi: 10.3390/tropicalmed5030115

35. Geiger A, Ponton F, Simo G. Adult blood-feeding tsetse flies, trypanosomes, microbiota and the fluctuating environment in sub-Saharan Africa. ISME J. (2015) 9:1496-507. doi: 10.1038/ismej.2014.236

36. Kaba D, Zacarie T, M'Pondi AM, Njiokou F, Bosson-Vanga H, Kröber T, et al. Standardising visual control devices for tsetse flies: central and west african species Glossina palpalis palpalis. PLoS Negl Trop Dis. (2014) 8:e2601. doi: 10.1371/journal.pntd.0002601

37. de Gier J, Cecchi G, Paone M, Dede P, Zhao W. The continental atlas of tsetse and African animal trypanosomosis in Nigeria. Acta Trop. (2020) 204:105328. doi: 10.1016/j.actatropica.2020.105328

38. Pépin J, Méda $H$. The epidemiology and control of human African trypanosomiasis. Adv Parasitol. (2001) 49:71-132. doi: 10.1016/S0065-308X(01)49038-5

39. Kagbadouno MS, Camara M, Rouamba J, Rayaisse J-B, Traoré IS, Camara O, et al. Epidemiology of sleeping sickness in Boffa (Guinea): where are the trypanosomes? PLoS Negl Trop Dis. (2012) 6:e1949. doi: 10.1371/journal.pntd.0001949

40. Rawlings P, Ceesay ML, Wacher TJ, Snow WF. The distribution of the tsetse flies Glossina morsitans submorsitans and G. palpalis gambiensis (Diptera: Glossinidae) in The Gambia and the application of survey results to tsetse and trypanosomiasis control. Bull Entomol Res. (1993) 83:625-32. doi: $10.1017 /$ S0007485300040050

41. Schneider DI, Saarman N, Onyango MG, Hyseni C, Opiro R, Echodu R, et al. Spatio-temporal distribution of Spiroplasma infections in the tsetse fly (Glossina fuscipes fuscipes) in northern Uganda. PLoS Negl Trop Dis. (2019) 13:e0007340. doi: 10.1371/journal.pntd.0007340

42. Aksoy S, Caccone A, Galvani AP, Okedi LM. Glossina fuscipes populations provide insigths for Human African Trypanosomiasis transmission in Uganda. Trends Parasitol. (2013) 29:394-406. doi: 10.1016/j.pt.2013.06.005 
43. Kaminsky R. Breeding sites of Glossina palpalis gambiensis and Glossina pallicera pallicera (Dipt., Glossinidae) in the leaf axils of oilpalms. Zeitschrift für Angew Entomol. (1984) 2:257-64.

44. Gouteux JP. Prevalence of enlarged salivary glands in Glossina palpalis, G. pallicera, and G. nigrofusca (Diptera: Glossinidae) from the Vavoua area, Ivory Coast. J Med Entomol. (1987) 24:268. doi: 10.1093/jmedent/ 24.2.268

45. Simo G, Fogue PS, Melachio TTT, Njiokou F, Kuiate JR, Asonganyi T. Population genetics of forest type of Trypanosoma congolense circulating in Glossina palpalis palpalis of Fontem in the South-West region of Cameroon. Parasites Vectors. (2014) 7:1-10. doi: 10.1186/17563305-7-385

46. FAO. Predicted Distributions of Tsetse in Africa [Internet]. Rome: FAO; AGAH; AHP (2000). Available online at: https://kdna.net/168-2011/africantryps/pdffilesofpapers/Predicteddistrioftsetse.pdf

47. Ndegwa PN, Irungu LW, Moloo SK. Effect of puparia incubation temperature : increased infection rates of Trypanosoma congolense. Med Vet Entomol. (1992) 127-30. doi: 10.1111/j.1365-2915.1992.tb00588.x

48. Courtin F, Rayaissé J, Tamboura I, Serdé O. Updating the Northern Tsetse Limit in Burkina Faso (1949-2009): impact of global change. Int J Environ Res Public Health. (2010) 1708-19. doi: 10.3390/ijerph7041708

49. Bengaly Z, Akoudjin M. Climate, cattle rearing systems and African animal trypanosomosis risk in Burkina Faso. PLoS ONE. (2012) 7:49762. doi: 10.1371/journal.pone.0049762

50. Abenga JN, Vuza D. About factors that determine trypanotolerance and prospects for increasing resistance against trypanosomosis. African $J$ Biotechnol. (2005) 4:1563-7. Available online at: https://www.ajol.info/index. php/ajb/article/view/71610

51. Stijlemans B, Brys L, Korf H, Bieniasz-Krzywiec P, Sparkes A, Vansintjan $\mathrm{L}$, et al. MIF-mediated hemodilution promotes pathogenic anemia in experimental African trypanosomosis. PLoS Pathog. (2016) 12:1005862. doi: 10.1371/journal.ppat.1005862

52. Radcliffe RW, Khairani KO. Health of the forest rhinoceros of southeast Asia: Sumatran and Javan rhinoceros. In: Eric Miller R, Lamberski N, Calle PP, editors. Fowler's Zoo and Wild Animal Medicine Current Therapy, Vol. 9, W.B. Saunders (2019). p. 707-15. doi: 10.1016/B978-0-323-55228-8.00100-4

53. Magona JW, Mayende JSP, Olaho-Mukani W, Coleman PG, Jonsson NN, Welburn SC, et al. A comparative study on the clinical, parasitological and molecular diagnosis of bovine trypanosomosis in Uganda. Onderstepoort $J$ Vet Res. (2003) 70:213-8.

54. Habila N, Inuwa MH, Aimola IA, Udeh MU, Haruna E. Pathogenic mechanisms of Trypanosoma evansi infections. Res Vet Sci. (2012) 2011:11. doi: 10.1016/j.rvsc.2011.08.011

55. Das SL, Angad G, Veterinary D. Trypanosomosis (Surra) in livestock. In: Katoch R, Rajesh Godara AY, editors. Veterinary Parasitology in Indian Perspective. 1st ed. New Delhi: Satish Serial Publishing House (2015). p. 305-30.

56. Mbaya A, Kumshe H, Okwudiri C. The mechanisms of anaemia in trypanosomosis: a review. Anemia. (2012) 2012:29530. doi: 10.5772/29530

57. Silva RAMS, Ramirez L, Souza SS, Ortiz AG, Pereira SR, Dávila AMR. Hematology of natural bovine trypanosomosis in the Brazilian Pantanal and Bolivian wetlands. Vet Parasitol. (1999) 85:87-93. doi: 10.1016/S0304-4017(99)00081-3

58. Luckins AG. Trypanosoma evansi in Asia. Parasitol Today. (1988) 4:137-42. doi: 10.1016/0169-4758(88)90188-3

59. Lisulo M, Sugimoto C, Kajino K, Hayashida K, Mudenda M, Moonga $\mathrm{L}$, et al. Determination of the prevalence of African trypanosome species in indigenous dogs of Mambwe district, eastern Zambia, by loop-mediated isothermal amplification. Parasites Vectors. (2014) 7:1-7. doi: 10.1186/1756-3305-7-19

60. Biéler S, Matovu E, Mitashi P, Ssewannyana E, Bi Shamamba SK, Bessell PR, et al. Improved detection of Trypanosoma brucei by lysis of red blood cells, concentration and LED fluorescence microscopy. Acta Trop. (2012) 121:135-40. doi: 10.1016/j.actatropica.2011.10.016

61. Woo PTK, Rogers D. A statistical study of the sensitivity of the haematocrit centrifuge technique in the detection of trypanosomes in blood. Trans $R$ Soc Trop Med Hyg. (1974) 68:319-26. doi: 10.1016/0035-9203(74)90041-8
62. Kirkpatrick CE. Dark-field microscopy for detection of some hemotropic parasites in blood smears of mammals and birds. Trans Am Microsc Soc. (1989) 108:190. doi: 10.2307/3226374

63. Marc D. Compendium of Standard Diagnostic Protocols for Animal Trypanosomoses of African Origin. Montpellier: CIRAD-OIE (2017). p. 106. Available online at: https://agritrop.cirad.fr/591960/

64. Veer S, Singla LD. Trypanosomosis in cattle and buffaloes from latent carrier status to clinical form of disease: Indian scenario. 2005. p. 10-18. Available online at: https://www.researchgate.net/profile/Lachhman-DasSingla/publication/261361614_Trypanosomosis_in_cattle_and_buffaloes_ from_latent_carrier_status_to_clinical_form_of_disease_Indian_scenario/ links/5686bb8d08aele63f1f5aa17/Trypanosomosis-in-cattle-and-buffaloesfrom-latent-carrier-status-to-clinical-form-of-disease-Indian-scenario.pdf

65. Chansiri K, Khuchareontaworn S, Nopporn S. PCR-ELISA for diagnosis of Trypanosoma evansi in animals and vector. Mol Cell Probes. (2002) 16:173-7. doi: $10.1006 /$ mcpr.2002.0412

66. Claes F, Radwanska M, Urakawa T, Majiwa PAO, Goddeeris B, Büscher P. Variable surface glycoprotein RoTat 1.2 PCR as a specific diagnostic tool for the detection of Trypanosoma evansi infections. Kinetoplastid Biol Dis. (2004) 3:3. doi: 10.1186/1475-9292-3-3

67. Muraleedharan K. Babesia and babesiosis in livestock of Karnataka State, India- an overview. Vet Res Int. (2015) 3:81-8. Available online at: http:/ jakraya.com/journal/pdf/1002-vriArticle_2.pdf

68. Thekisoe OMM, Kuboki N, Nambota A, Fujisaki K, Sugimoto C, Igarashi I, et al. Species-specific loop-mediated isothermal amplification (LAMP) for diagnosis of trypanosomosis. Acta Trop. (2007) 102:182-9. doi: 10.1016/j.actatropica.2007.05.004

69. Kumar R, Dilbaghi N, Kumar S, Gupta AK, Khurana SK, Yadav SC. Development of lateral flow assay for point-of-care diagnosis of trypanosomosis in equines. J Equine Vet Sci. (2018) 70:1-6. doi: 10.1016/j.jevs.2018.07.007

70. Oie. Trypanosomosis (tsetse-transmitted). (2013). Available online at: www.oie.int/fileadmin/Home/eng/.in./TRYPANO_TSETSE.pdf (accessed May 1-5, 2013).

71. Mbaya AW, Aliyu MM, Ibrahim UI. The clinico-pathology and mechanisms of trypanosomosis in captive and free-living wild animals: a review. Vet Res Commun. (2009) 33:793-809. doi: 10.1007/s11259-009-9214-7

72. Pathak KML, Arora JK, Kapoor M. Camel trypanosomosis in Rajasthan, India. Vet Parasitol. (1993) 49:319-23. doi: 10.1016/0304-4017(93)90130-F

73. Lejon V, Büscher P, Nzoumbou-Boko R, Bossard G, Jamonneau V, Bucheton $B$, et al. The separation of trypanosomes from blood by anion exchange chromatography: from Sheila Lanham's discovery 50 years ago to a gold standard for sleeping sickness diagnosis. PLoS Negl Trop Dis. (2019) 13:e0007051. doi: 10.1371/journal.pntd.0007051

74. Gutierrez C, Corbera JA, Doreste F, Büscher P. Use of the miniature anion exchange centrifugation technique to isolate Trypanosoma evansi from goats. Ann N Y Acad Sci. (2004) 1026:149-51. doi: 10.1196/annals.1307.020

75. Lumsden WHR, Kimber CD, Evans DA, Doig SJ. Trypanosoma brucei: miniature anion-exchange centrifugation technique for detection of low parasitaemias: adaptation for field use. Trans R Soc Trop Med Hyg. (1979) 73:312-7. doi: 10.1016/0035-9203(79)90092-0

76. Ndungu K, Thungu D, Wamwiri F, Mireji P, Ngae G, Gitonga P, et al. Route of inoculation influences Trypanosoma congolense and Trypanosoma brucei brucei virulence in Swiss white mice. PLoS ONE. (2019) 14:e0218441. doi: 10.1371/journal.pone.0218441

77. Ruiz AM, Esteva M, Cabeza Meckert P, Laguens RP, Segura EL. Protective immunity and pathology induced by inoculation of micewith different subcellular fractions of Trypanosoma cruzi. Acta Trop. (1985) 42:299-309.

78. Melo RC, Brener Z. Tissue tropism of different Trypanosoma cruzi strains. J Parasitol. (1978) 64:475-82. doi: 10.2307/3279787

79. Morlais I, Ravel S, Grébaut P, Dumas V, Cuny G. New molecular marker for Trypanosoma (Duttonella) vivax identification. Acta Trop. (2001) 80:207-13. doi: 10.1016/S0001-706X(01)00160-7

80. Marc D, Ketsarin K, Sarawut Y, Cristina M, Sophie R, Wang MH, et al. Specific primers for PCR amplification of the ITS1 (ribosomal DNA) of Trypanosoma lewisi. Infect Genet Evol. (2011) 11:1361-7. doi: 10.1016/j.meegid.2011.04.030 
81. Meyer Zum Büschenfelde C, Cramer S, Trumpfheller C, Fleischer B, Frosch S. Trypanosoma cruzi induces strong IL-12 and IL-18 gene expression in vivo : correlation with interferon-gamma (IFN- $\gamma$ ) production. Clin Exp Immunol. (1997) 110:378-85. doi: 10.1046/j.1365-2249.1997.4471463.x

82. Vorraro F, Cabrera WHK, Ribeiro OG, Jensen JR, De Franco M, Ibañez OM, et al. Trypanosoma cruzi infection in genetically selected mouse lines: genetic linkage with quantitative trait locus controlling antibody response. Mediators Inflamm. (2014) 2014:952857. doi: 10.1155/2014/952857

83. Pinto Torres JE, Goossens J, Ding J, Li Z, Lu S, Vertommen D, et al. Development of a Nanobody-based lateral flow assay to detect active Trypanosoma congolense infections. Sci Rep. (2018) 8:1-15. doi: 10.1038/s41598-018-26732-7

84. Katende JM, Nantulya VM, Musoke AJ. Comparison between bloodstream and procyclic form trypanosomes for serological diagnosis of African human trypanosomiasis. Trans R Soc Trop Med Hyg. (1987) 81:607-8. doi: 10.1016/0035-9203(87)90425-1

85. Ribone ME, Belluzo MS, Pagani D, Marcipar IS, Lagier CM. Amperometric bioelectrode for specific human immunoglobulin $G$ determination: optimization of the method to diagnose American trypanosomiasis. Anal Biochem. (2006) 350:61-70. doi: 10.1016/j.ab.2005.11.033

86. Semballa S, Okomo-Assoumou MC, Holzmuller P, Büscher P, Magez S, Lemesre JL, et al. Identification of a tryptophan-like epitope borne by the variable surface glycoprotein (VSG) of African trypanosomes. Exp Parasitol. (2007) 115:173-80. doi: 10.1016/j.exppara.2006.08.008

87. Cappa SMG, Vattuone NH, Menes S, Schmuñis GA. Humoral antibody response and Ig characterization of the specific agglutinins in rabbits during experimental American trypanosomiasis. Exp Parasitol. (1973) 34:32-9. doi: 10.1016/0014-4894(73)90059-3

88. Thompson CK, Thompson RCA. Trypanosomes of Australian mammals: knowledge gaps regarding transmission and biosecurity. Trends Parasitol. (2015) 31:553-62. doi: 10.1016/j.pt.2015.06.011

89. McKeever S, Gorman GW, Norman L. Occurrence of a Trypanosoma cruzi-like organism in some mammals from Southwestern Georgia and Northwestern Florida. J Parasitol. (1958) 44:583. doi: 10.2307/3274538

90. Olsen PF, Shoemaker JP, Turner HF, Hays KL. Incidence of Trypanosoma cruzi (Chagas) in wild vectors and reservoirs in East-Central Alabama. $J$ Parasitol. (1964) 50:599. doi: 10.2307/3276112

91. Lanham SM, Godfrey DG. Isolation of salivarian trypanosomes from man and other mammals using DEAE-cellulose. Exp Parasitol. (1970) 28:521-34. doi: 10.1016/0014-4894(70)90120-7

92. Hernández-Orts JS, Montero FE, García NA, Crespo EA, Raga JA, GarcíaVarela M, et al. Transmission of Corynosoma australe (Acanthocephala: Polymorphidae) from fishes to South American sea lions Otaria flavescens in Patagonia, Argentina. Parasitol Res. (2019) 118:433-40. doi: $10.1007 / \mathrm{s} 00436-018-6177-\mathrm{z}$

93. Hall SR, Lafferty KD, Brown JH, Cáceres CE, Chase JM, Dobson AP, et al. Chapter Ten Is Infectious Disease Just Another Type of PredatorPrey Interaction? In: Infectious Disease Ecology: Effects of Ecosystems on Disease and of Disease on Ecosystems. Cambridge: Princeton University Press (2005). p. 223-41. Available online at: https://www.jstor.org/stable/j.ctt7sgg4 (accessed October 19, 2020)

94. Brun R, Hecker H, Lun Z-R. Trypanosoma evansi and T. equiperdum: distribution, biology, treatment and phylogenetic relationship (a review). Vet Parasitol. (1998) 79:95-107. doi: 10.1016/S0304-4017(98)00146-0

95. Haag J. The molecular phylogeny of trypanosomes: evidence for an early divergence of the Salivaria. Mol Biochem Parasitol. (1998) 91:37-49. doi: 10.1016/S0166-6851(97)00185-0

96. Geerts S, Osaer S, Goossens B, Faye D. Trypanotolerance in small ruminants of sub-Saharan Africa. Trends Parasitol. (2009) 25132-8. doi: $10.1016 /$ j.pt.2008.12.004

97. Giordani F, Morrison LJ, Rowan TG, De Koning HP, Barrett MP. The animal trypanosomiases and their chemotherapy: a review. Parasitology. (2016) 143:1862-89. doi: 10.1017/S0031182016001268

98. Shah SS, Khan A. One health and parasites. In: Yasobant S, Saxena D, editors. Global Applications of One Health Practice and Care. IGI Global (2019). p. 82-112. doi: 10.4018/978-1-5225-6304-4.ch004
99. Jaffe JJ, McCormack JJ, Gutteridge WE. Dihydrofolate reductases within the genus Trypanosoma. Exp Parasitol. (1969) 25:311-8. doi: 10.1016/0014-4894(69)90076-9

100. Radwanska M, Vereecke N, Deleeuw V, Pinto J, Magez S. Salivarian trypanosomosis: a review of parasites involved, their global distribution and their interaction with the innate and adaptive mammalian host immune system. Front Immunol. (2018) 9:2253. doi: 10.3389/fimmu.2018.02253

101. Welburn S, Picozzi K, Coleman PG, Packer C. Patterns in age-seroprevalence consistent with acquired immunity against Trypanosoma brucei in Serengeti Lions. PLoS Negl Trop Dis. (2008) 2:e347. doi: 10.1371/journal.pntd.0000347

102. Black SJ, Mansfield JM. Prospects for vaccination against pathogenic African trypanosomes. Parasite Immunol. (2016) 38:735-43. doi: 10.1111/pim.12387

103. Reichard RE. Area-wide biological control of disease vectors and agents affecting wildlife. OIE Rev Sci Tech. (2002) 21:179-85. doi: 10.20506/rst.21.1.1325

104. Sudan V, Verma AK, Jaiswal AK. Trypanosomosis of wild animals with emphasis on Indian scenario. Vet Parasitol. (2017) 10:25-8. doi: 10.1016/j.vprsr.2017.07.003

105. Begna F, Abebe S, Bekele M. Bovine trypanosomosis in selected villages of Humbo District, Southern Ethiopia. Glob Vet. (2011) 7:192-8. Available online at: https://www.idosi.org/gv/GV7(2)11/16.pdf

106. Murray M, Morrison WI, Whitelaw DD. Host susceptibility to african trypanosomiasis: trypanotolerance. Adv Parasitol. (1982) 21:1-68. doi: 10.1016/S0065-308X(08)60274-2

107. Kelvin N, Anna BE, Peter JH, Paul SG. Assessing risk factors for trypanosome infections in cattle in wildlife interface areas in Northern Tanzania. J Infect Dis Epidemiol. (2019) 5:1510078. doi: 10.23937/2474-3658/1510078

108. Kasozi KI, Namayanja M, Gaithuma AK, Mahero M, Matovu E, Yamagishi $\mathrm{J}$, et al. Prevalence of hemoprotozoan parasites in small ruminants along a human-livestock-wildlife interface in western Uganda. Vet Parasitol Reg Stud Rep. (2019) 87:100309. doi: 10.1016/j.vprsr.2019.100309

109. Sarabian C, Curtis V, McMullan R. Evolution of pathogen and parasite avoidance behaviours. Philos Trans R Soc B Biol Sci. (2018) 373:20170256. doi: 10.1098/rstb.2017.0256

110. Wang J, Van Praagh A, Hamilton E, Wang Q, Zou B, Muranjan M, et al. Serum xanthine oxidase: origin, regulation, and contribution to control of trypanosome parasitemia. Antioxid Redox Signal. (2002) 4:161-78. doi: $10.1089 / 152308602753625933$

111. Naessens J, Grab DJ, Sileghem M. Identifying the mechanisms of trypanotolerance in cattle. In: The African Trypanosomes. Boston: Kluwer Academic Publishers (2005). p. 97-111. Available online at: http://link. springer.com/10.1007/0-306-46894-8_8 (accessed October 17, 2020).

112. Wang Q, Murphy N, Black SJ. Infection-associated decline of Cape buffalo blood catalase augments serum trypanocidal activity. Infect Immun. (1999) 67:2797-803. doi: 10.1128/IAI.67.6.2797-2803.1999

113. Paglia DE, Miller RE. Red blood cell metabolism in the black rhinoceros (Diceros bicornis). Eur Assoc Zoo Wildl Vet. (1996) 5:243-5.

114. Estes RD. The comparative behavior of grant's and Thomson's gazelles. $J$ Mammal. (1967) 48:189. doi: 10.2307/1378022

115. Mortelmans J, Kageruka P. Trypanotolerant cattle breeds in Zaire. In: Flnelle P, Murray M, Barry JD, Morrison WI, WilliamsRO, Hirum H, Rovis L, Mortelmans J, Kageruka P, Murray M, Morrison WI, Murray PK, Clifford DS, Trail JCM, Maclennan KJR, Letenneur L, editors. African Animal Trypanosomiasis Selected Articles From the World Animal Review. Rome: Food and Agriculture Organization of the United Nations (1983). Available online at: http://www.fao.org/3/ah809e/AH809E00.htm\#Contents

116. Ashcroft MT, Burtt E, Fairbairn H. Annals of tropical medicine \& parasitology the experimental infection of some african wild animals with trypanosoma rhodesiense, T. Brucei. Ann Trop Med Parasitol. (1959) 4983:147-61. doi: 10.1080/00034983.1959.11685912

117. Van den Bossche P, Delespaux V. Options for the control of tsetsetransmitted livestock trypanosomosis. an epidemiological perspective. Vet Parasitol. (2011) 181:37-42. doi: 10.1016/j.vetpar.2011.04.021

118. Peterson MN, Birckhead JL, Leong K, Peterson MJ, Peterson TR Rearticulating the myth of human-wildlife conflict. Conserv Lett. (2010) 3:74-82. doi: 10.1111/j.1755-263X.2010.00099.x 
119. Thompson CK, Godfrey SS, Thompson RCA. Trypanosomes of Australian mammals: a review. Int J Parasitol Parasites Wildl. (2014) 3:57-66. doi: 10.1016/j.ijppaw.2014.02.002

120. Barua M, Bhagwat SA, Jadhav S. The hidden dimensions of human-wildlife conflict: health impacts, opportunity and transaction costs. Biol Conserv. (2013) 157:309-16. doi: 10.1016/j.biocon.2012.07.014

121. Ohemeng F, Ayivor JS, Lawson ET, Ntiamoa-Baidu Y. Local classifications of fever and treatment sought among populations at risk of zoonotic diseases in Ghana. PLoS ONE. (2018) 13:e0201526. doi: 10.1371/journal.pone.0201526

122. Miller RS, Sweeney SJ, Slootmaker C, Grear DA, Di Salvo PA, Kiser D, et al. Cross-species transmission potential between wild pigs, livestock, poultry, wildlife, and humans: implications for disease risk management in North America. Sci Rep. (2017) 7:7821. doi: 10.1038/s41598-017-07336-Z

123. Borremans B, Faust C, Manlove KR, Sokolow SH, Lloyd-Smith JO. Cross-species pathogen spillover across ecosystem boundaries: mechanisms and theory. Philos Trans R Soc B Biol Sci. (2019) 374:20180344. doi: 10.1098/rstb.2018.0344

124. Atuman Y, Kudi CA, Abdu P, Abubakar A. Prevalence of parasites of wildlife in Yankari game reserve and Sumu wildlife park in Bauchi State, Nigeria. Sokoto J Vet Sci. (2020) 17:70-9. doi: 10.4314/sokjvs.v17i4.8

125. Gondwe N, Marcotty T, Vanwambeke SO, Pus C De, Mulumba M, Van Den Bossche P. Distribution and density of tsetse flies (glossinidae: Diptera) at the game/people/livestock interface of the nkhotakota game reserve human sleeping sickness focus in malawi. Ecohealth. (2009) 6:260-5. doi: 10.1007/s10393-009-0252-y

126. Kaare MT, Picozzi K, Mlengeya T, Fèvre EM, Mellau LS, Mtambo MM, et al. Sleeping sickness-a re-emerging disease in the Serengeti? Travel Med Infect Dis. (2007) 5:117-24. doi: 10.1016/j.tmaid.2006.01.014

127. Mwiinde AM, Simuunza M, Namangala B, Chama-Chiliba CM, Machila $\mathrm{N}$, Anderson N, et al. Estimating the economic and social consequences for patients diagnosed with human African trypanosomiasis in Muchinga, Lusaka and Eastern Provinces of Zambia (2004-2014). Infect Dis Poverty. (2017) 6:150. doi: 10.1186/s40249-017-0363-6

128. Anderson NE, Mubanga J, Machila N, Atkinson PM, Dzingirai V, Welburn SC. Sleeping sickness and its relationship with development and biodiversity conservation in the Luangwa Valley, Zambia. Parasit Vectors. (2015) 8:224. doi: 10.1186/s13071-015-0827-0

129. Alderton S, Macleod ET, Anderson NE, Machila N, Simuunza M, Welburn $\mathrm{SC}$, et al. Exploring the effect of human and animal population growth on vector-borne disease transmission with an agent-based model of Rhodesian human African trypanosomiasis in eastern province, Zambia. PLoS Negl Trop Dis. (2018) 12:e0006905. doi: 10.1371/journal.pntd.0006905

130. Alderton S, Macleod ET, Anderson NE, Palmer G, Machila N, Simuunza $\mathrm{M}$, et al. An agent-based model of tsetse fly response to seasonal climatic drivers: assessing the impact on sleeping sickness transmission rates. PLoS Negl Trop Dis. (2018) 12:e0006188. doi: 10.1371/journal.pntd. 0006188

131. Rademaker V, Herrera HM, Raffel TR, D’Andrea PS, Freitas TPT, Abreu UGP, et al. What is the role of small rodents in the transmission cycle of Trypanosoma cruzi and Trypanosoma evansi (Kinetoplastida Trypanosomatidae)? A study case in the Brazilian Pantanal. Acta Trop. (2009) 111:102-7. doi: 10.1016/j.actatropica.2009.02.006

132. Auty H, Morrison LJ, Torr SJ, Lord J. Transmission dynamics of rhodesian sleeping sickness at the interface of wildlife and livestock areas. Trends Parasitol. (2016) 32:608-21. doi: 10.1016/j.pt.2016.05.003

133. Lord JS, Mthombothi Z, Lagat VK, Atuhaire F, Hargrove JW. Hostseeking efficiency can explain population dynamics of the tsetse fly Glossina morsitans morsitans in response to host density decline. PLoS Negl Trop Dis. (2017) 11:e0005730. doi: 10.1371/journal.pntd.0005730

134. Dickman AJ. Complexities of conflict: the importance of considering social factors for effectively resolving human-wildlife conflict. Anim Conserv. (2010) 13:458-66. doi: 10.1111/j.1469-1795.2010.00368.x

135. Manfredo MJ, Dayer AA. Concepts for exploring the social aspects of Human-Wildlife conflict in a global context. Hum Dimens Wildl. (2004) 9:1-20. doi: 10.1080/10871200490505765

136. Van den Bossche $\mathrm{P}$. Some general aspects of the distribution and epidemiology of bovine trypanosomosis in southern Africa. Int J Parasitol. (2001) 1:592-8. doi: 10.1016/S0020-7519(01)00146-1
137. Nonga HE, Kambarage DM. Prevalence of Bovine trypanosomosis in Morogoro, Tanzania. Pakistan J Nutr. (2009) 8:208-13. doi: 10.3923/pjn.2009.208.213

138. Vreysen MJB, Seck MT, Sall B, Bouyer J. Tsetse flies: their biology and control using area-wide integrated pest management approaches. J Invertebr Pathol. (2013) 112(Suppl.1):S15-25. doi: 10.1016/j.jip.2012.07.026

139. Osofsky SA, Kock RA, Kock MD, Kalema-Zikusoka G, Grahn R, Karesh WB. Building Support for Protected Areas Using a "One Health" Perspective. Friends for Life New Partners in Support of Protected Areas. (2005). p. 65-79. Available online at: https://vtechworks.lib.vt.edu/handle/10919/65901

140. Kolbe FF, Senekal OFS. The status of the tsetse flies in relation to game conservation and utilization. South African J Wildl Res. (1974) 4:43-9.

141. Holmes PH. New approaches to the integrated control of trypanosomosis. Vet Parasitol. (1997) 71:121-35. doi: 10.1016/S0304-4017(97)00026-5

142. Allsopp R. Control of tsetse flies (Diptera: Glossinidae) using insecticides: a review and future prospects. Bull Entomol Res. (1984) 74:1-23. doi: $10.1017 /$ S0007485300009895

143. Rayaisse JB, Tirados I, Kaba D, Dewhirst SY, Logan JG, Diarrassouba A, et al. Prospects for the development of odour baits to control the tsetse flies Glossina tachinoidesand G. palpalis s.l. PLoS Negl Trop Dis. (2010) 4:632. doi: 10.1371/journal.pntd.0000632

144. Welburn SC, Coleman P. Human and animal African trypanosomiasis. In: One Health: The Theory and Practice of Integrated Health Approaches. Wallingford: CABI (2015). p. 201-21. Available online at: http://www.cabi. org/cabebooks/ebook/20153067417 (accessed October 17, 2020).

145. Eyob E, Matios L. Review on camel trypanosomosis (surra) due to Trypanosoma evansi: epidemiology and host response. J Vet Med Anim Heal. (2013) 5:334-43. Available online at: https://academicjournals.org/journal/ JVMAH/article-full-text-pdf/4BAB67841636

146. Randolph DG, Refisch J, MacMillan S, Wright CY, Bett B, Robinson $\mathrm{D}$, et al. Understanding the linkages between habitat loss, the trade and use of wildlife, and the emergency of novel zoonoses. In: Zoonotic Diseases and How to Break the Chain of Transmission. (2020). p. 2934. Available online at: https://wedocs.unep.org/bitstream/handle/20.500. 11822/32316/ZP.pdf? sequence=1\&isAllowed=y (accessed October 17, 2020).

147. Weise FJ, Fynn RWS, Stein AB, Tomeletso M, Somers MJ, Périquet S Seasonal selection of key resources by cattle in a mixed savannah-wetland ecosystem increases the potential for conflict with lions. Biol Conserv. (2019) 237:253-66. doi: 10.1016/j.biocon.2019.06.031

148. Ahmad CB, Abdullah J, Jaafar J. Community perspectives on buffer zone for protected areas: a preliminary study. Procedia Soc Behav Sci. (2013) 85:198-205. doi: 10.1016/j.sbspro.2013.08.351

149. Kideghesho JR. Co-existence between the traditional societies and wildlife in western Serengeti, Tanzania: its relevancy in contemporary wildlife conservation efforts. Biodivers Conserv. (2008) 17:1861-81. doi: 10.1007/s10531-007-9306-z

150. Taylor RD, Martin RB. Effects of veterinary fences on Wildlife conservation in Zimbabwe. Environ Manage. (1987) 11:327-34. doi: 10.1007/BF01867160

151. Baral N, Heinen JT. Decentralization and people's participation in conservation: a comparative study from the Western Terai of Nepal. Int $J$ Sustain Dev World Ecol. (2007) 14:520-31. doi: 10.1080/13504500709469751

152. Kameri-Mbote P. Land tenure, land use, and sustainability in kenya: toward innovative use of property rights in wildlife management. In: Chalifour NJ, Kameri-Mbote P, Lye LH, Nolon JR, editors. Land Use Law for Sustainable Development Cambridge: Cambridge University Press (2006). p. 132-60. doi: 10.1017/CBO9780511511400.012

153. Lima L, Silva FM da, Neves L, Attias M, Takata CSA, Campaner $\mathrm{M}$, et al. Evolutionary insights from bat trypanosomes: morphological, developmental and phylogenetic evidence of a new species, Trypanosoma (Schizotrypanum) erneyi sp. nov., in African Bats Closely Related to Trypanosoma (Schizotrypanum) cruzi and allied species. Protist. (2012) 163:856-72. doi: 10.1016/j.protis.2011.12.003

154. Pinto CM, Ocaña-Mayorga S, Tapia EE, Lobos SE, Zurita AP, Aguirre-Villacís $\mathrm{F}$, et al. Bats, trypanosomes, and triatomines in Ecuador: new insights into the diversity, transmission, and origins of Trypanosoma cruzi and Chagas disease. PLOS ONE. (2015) 10:e0139999. doi: 10.1371/journal.pone.0139999

155. Cavazzana M, Marcili A, Lima L, da Silva FM, Junqueira ÂCV, Veludo HH, et al. Phylogeographical, ecological and biological patterns shown by nuclear 
(ssrRNA and gGAPDH) and mitochondrial (Cyt b) genes of trypanosomes of the subgenus Schizotrypanum parasitic in Brazilian bats. Int J Parasitol. (2010) 40:345-55. doi: 10.1016/j.ijpara.2009.08.015

156. Baral TN. Immunobiology of African trypanosomes: need of alternative interventions. J Biomed Biotechnol. (2010) 2010:389153. doi: $10.1155 / 2010 / 389153$

157. Stijlemans B, Radwanska M, Trez C De, Magez S. African trypanosomes undermine humoral responses and vaccine development: link with inflammatory responses? Front Immunol. (2017) 8:1. doi: 10.3389/fimmu.2017.00582

158. La Greca F, Magez S. Vaccination against trypanosomiasis. Hum Vaccin. (2011) 7:1225-33. doi: 10.4161/hv.7.11.18203

159. Muhammad G, Saqib M, Sajid MS, Naureen A. Trypanosoma evansi infections in Himalayan black bears (Selenarctos thibetanus). J Zoo Wildl Med. (2007) 38:97-100. doi: 10.1638/06-024.1

160. Botero A, Keatley S, Peacock C, Thompson RCA. In vitro drug susceptibility of two strains of the wildlife trypanosome, Trypanosoma copemani: a comparison with Trypanosoma cruzi. Int J Parasitol Drugs Drug Resist. (2017) 7:34-41. doi: 10.1016/j.ijpddr.2016.12.004

161. Argañaraz ER, Hubbard GB, Ramos LA, Ford AL, Nitz N, Leland $\mathrm{MM}$, et al. Blood-sucking lice may disseminate Trypanosoma cruzi infection in baboons. Rev Inst Med Trop São Paulo. (2001) 43:271-6. doi: 10.1590/S0036-46652001000500007

162. Garcia HA, Rangel CJ, Ortíz PA, Calzadilla CO, Coronado RA, Silva AJ, et al. Zoonotic trypanosomes in rats and fleas of venezuelan slums. Ecohealth. (2019) 16:523-33. doi: 10.1007/s10393-019-01440-4

163. Lizundia R, Newman C, Buesching CD, Ngugi D, Blake D, Sin YW, et al. Evidence for a role of the host-specific flea (Paraceras melis) in the transmission of Trypanosoma (Megatrypanum) pestanai to the European Badger. PLoS ONE. (2011) 6:e16977. doi: 10.1371/journal.pone.00 16977

164. Schwan TG, Lopez JE, Safronetz D, Anderson JM, Fischer RJ, Maïga O, et al. Fleas and trypanosomes of peridomestic small mammals in sub-
Saharan Mali. Parasit Vectors. (2016) 9:1-7. doi: 10.1186/s13071-016-1 818-5

165. Votýpka J, Suková E, Kraeva N, Ishemgulova A, DuŽí I, Lukeš J, et al. Diversity of Trypanosomatids (Kinetoplastea: Trypanosomatidae) parasitizing fleas (Insecta: Siphonaptera) and description of a New Genus Blechomonas gen. n. Protist. (2013) 164:763-81. doi: 10.1016/j.protis.2013.08.002

166. Magona JW, Mayende JSP. Occurrence of concurrent trypanosomosis, theileriosis, anaplasmosis and helminthosis in Friesian, Zebu and Sahiwal cattle in Uganda. Onderstepoort J Vet Res. (2002) 140:133-40. Available online at: https://repository.up.ac.za/bitstream/handle/2263/ 18297/13magona2002.pdf? sequence $=1$ \&isAllowed $=y$

167. Nesbitt ST, Njau BC, Otieno LH. Epizootiology of trypanosomiasis in Lambwe Valley, Kenya, East Africa. Int J Trop Insect Sci. (1991) 12:379-84. doi: 10.1017/S1742758400011243

168. Northover AS, Godfrey SS, Keatley S, Lymbery AJ, Wayne AF, Cooper C, et al. Increased Trypanosoma spp. richness and prevalence of haemoparasite co-infection following translocation. Parasit Vectors. (2019) 12:1-14. doi: 10.1186/s13071-019-3370-6

Conflict of Interest: The authors declare that the research was conducted in the absence of any commercial or financial relationships that could be construed as a potential conflict of interest.

Copyright (c) 2021 Kasozi, Zirintunda, Ssempijja, Buyinza, Alzahrani, Matama, Nakimbugwe, Alkazmi, Onanyang, Bogere, Ochieng, Islam, Matovu, Nalumenya, Batiha, Osuwat, Abdelhamid, Shen, Omadang and Welburn. This is an open-access article distributed under the terms of the Creative Commons Attribution License (CC $B Y)$. The use, distribution or reproduction in other forums is permitted, provided the original author(s) and the copyright owner(s) are credited and that the original publication in this journal is cited, in accordance with accepted academic practice. No use, distribution or reproduction is permitted which does not comply with these terms. 